(c) Although the slowing with age, observed in the face of additional information challenge, is equivalent to reducing the rate of transmission of information, it does not unequivocally suggest a reduced capacity for discrimination and choice. It may mean, for example, that the forms of encoding and decoding operations performed by the brain are adjusted to the characteristics of the available channel according to the nature of prevailing input and the weight assigned to other inputs. Until more plausible theoretical conceptions are brought to bear on the problem at issue, the factor limiting decision and short-term storage processes among the older adults appears to be in the nature of an increased 'noise-level' in the central nervous system. Moreover, assuming that the agreement between the findings from psychological and cardiorascular tests is not misleading, it is possible to speculate further that a reduced rate of cerebral blood flow may contribute to the hypothetical random activity in brain cells.

This work is supported by a grant from tho U.S. National Institutes of Health $(R G-7646)$.

\section{JACEK SzAFraN}

Department of Experimental Psychology,

Lovelace Foundation,

Albuquerque.

New- Mexico.

${ }^{1}$ Welford, A. T. Gerontologia . 5, 129 (1961).

Hick, W. L., Quart, J Exp. Psychol, 4. 11 (1952).

${ }^{3}$ Crossman, E. K. F. W., and Szafran, J., Experientia, Suppl., 4, 128 (1956).

+ (Gregory, R. L., Pror. Fourth Intern. Cong. Gerontol. (Merano, 1957).

'Tanner, W. P., and swets, J. A., Psychol. Rev., 61, 401 (1954).

'Poulton. E. C., Frgonomics, 1. 234 (1958).

Schouten. J. F., Kitsberk, J. W. H., and Lcopold, F. F., Ergonomics, 5 , $251\left(196^{\circ}\right)$.

${ }^{5}$ Williams, A. C... and Hopkins, C. O., WADC Tech. Rep. 58-522, W-PA Fls Ohio, 1958)

Poulton, E. C.. in Human Problems of Supersonic and Hypersonic Flight (London, 196\%)

30 Bartlett, F. C., Proc. Roy. Soc., B, 131, 247 (1943).

"Welford, N. T., J. Sci. Inst. 29, 1 (1952).

${ }^{12}$ Lee, B. S., J. Acoust. Soc. Amer., 22, 824 (1950).

${ }^{13}$ Hamilton, W. F. (ed.), Handbook of Physiology, Section 2, 1 (Washington, D.C., 1962).

"Szafran, J., Proc. Fifth Intern. Cong. Gerontol. (San Francisco, 1960)

${ }^{15}$ Brebner, J., and Szafran, J., Nature, 190, 195 (1961).

${ }^{16}$ Kendall, M. G., Rank Correlation Methods (London, 1948).

${ }^{17}$ Welford, A. T. in Hardbook of Ageing and the Individual, edit, by Birren, J. E. (Chicago, 1959).

is Szafran, J., Proc. Sixth Intern. Cong. Gerontol. (Plenary Session) (Copenhagen, 1963 ).

\section{RADIOBIOLOGY}

\section{Transmission of Ultra-violet Rays in Quartz Fibres}

ULTrA-violet rays cannot penetrate deeply into tissues ; consequently, investigations of their biological effects have been limited to unicollular forms, cells in tissue culture, and the surface cells of organs and organisms. In my apparatus designed for conducting ultra-violet photons to the deeper cells of the brain, ponetration of the tissue is achieved with quartz fibres which act as conductors for the energies under consideration.

These quartz fibres are mado by hoating a small section of a clear fused quartz rod $4 \mathrm{~mm}$ in diameter in the hottest part of a gas-oxygen flame. When the quartz becomes white hot, it is pulled into a fibre as it is moved into the cooler part of the flame. The fibre is then broken. Each resulting pieco of quartz has a large end, which is oqual in diameter to the original rod, a tapering portion about $10 \mathrm{~mm}$ long, and a terminal fibre $10-40 \mathrm{~mm}$ long. With a little practice, one can make fibres having tips less than $10 \mu$ in diameter. The tip of the fibre can be pushed into the brain of a chick embryo with comparatively little disruption of the tissue.
The large end of the quartz rod is fixed in a hole in the housing of a low-pressure mercury are lamp, a source which emits much of its energy at $2537 \AA$. The behaviour of ultra-violet photons is observed by placing the rod and its terminal fibre next to the concave surface of a fragment from an ordinary fluorescent lighting tube. The phosphor contained on the inner surface displays a white fluorescence when it absorbs photons in the $2537 \AA$ line. Trans. mission of these photons is demonstrated by placing a filter between the mercury arc source and the large end of the rod; the filter transmits the $2537 \AA$ line plus some blue light. Using micromanipulation apparatus, the fibre is brought into contact with the phosphor. Under magnification, the blue light visible in the fibre is readily distinguished from the whole light which indicates excitation of the phosphor.

Most of the rays which enter the quartz escape from it in the tapering portion; although their angle of incidence on the quartz-air interface is greater than the critical angle for ultra-violet in these media, repeated internal reflexion rapidly reduces this angle of incidence. Some of the rays. however, enter the terminal fibre, and are conducted to its tip. Tho cmerging cone of energy is fairly well col. limated after its passage through the fibre, and its physical effects can be delineated.

Hinrichs ${ }^{1-3}$ and Hinrichs and Warrick ${ }^{4}$ used a pointed quartz rod to direct radiation from a mercury are against small surface areas of chick embryos and fundulus hearts. It is possible that much of the energy conducted in their rods was in the ultra-violot range. It must be pointed out, however, that a fair amount of radiant heat is emitted by a mercury are lamp; such energy is conducted in quartz by internal reflexion, and may have caused the damage observod by Hinrichs and Warrick in the target tissues. Using a suitable phosphor as a target, it is possible to demonstrate the transmission of ultra-violet rays in quartz fibres.

This work was supported by a grant from the Committee on Institutional Research of Meharry Medical College and by grant $N B \quad 04324$ from the National Institute of Neurological Disoases and Blindness.

\section{J. Baskerville Hyde}

Department of Anatomy,

Meharry Medical College,

Nashville 8, Tennessee.

${ }^{3}$ Hinrichs, M. A., J. Exp. Zool., 47, 309 (1927).

2 Hinrichs, M. A., Proc, Soc. Exp. Biol. Med., 27, 354 (1930).

${ }^{3}$ Hinrichs, M. A., Proc. Soc. Exp. Biol. Med., 28, 1059 (1931)

"Hinrichs, M. A., and Warrick, G., Proc. Soc. Exp. Biol. Med., 28, $105 \bar{t}$ (1931).

\section{Multiple Anomalies occurring in a New-born Spanish Goat following Prenatal Gamma- radiation}

A UNIQUE and complex combination of abnormalities occurred in a Spanish goat (genus Capra) following prenatal irradiation. The dam, a vigorous 3 -year-old, was subjected to radiation from a cobalt-60 source $^{1}$ on the 30 th day of pregnancy. Dosage was $300 \mathrm{r}$. administered at $100 \mathrm{r} . \mathrm{h}$.

Following a normal gestation period of 150 days, the doe gave birth to a female kid weighing $4.3 \mathrm{lb}$. Average weight for irradiated single kids in the flock was $5 \cdot 2 \mathrm{lb}$.

A number of aberrations were immediately apparent in the animal. Functionally the most obvious was the animal's lack of muscular control and inability to rise or stand. It was quite vigorous vocally and emitted sounds normal for its species and age. The back was held in a rigid straight line, and all limbs were extended backward and parallel with the spinal column. The head was drawn downward with the jaw near the chest, which gave a pronounced arched appearance to the neck. 